\title{
Occult Hepatitis C Virus Infection among Hemodialysis Patients: An Iranian Experience
}

\author{
Sedigheh Taherpour, MD"; Davod Javanmard, $\mathrm{PhD}^{1,2}$; Masood Ziaee, $\mathrm{MD}^{1 *}$ \\ ${ }^{1}$ Infectious Diseases Research Center, Birjand University of Medical Sciences, Birjand, Iran \\ ${ }^{2}$ Department of Medical Microbiology, Faculty of Medicine, Birjand University of Medical Sciences, Birjand, Iran
}

\begin{abstract}
Background: Patients with chronic kidney failure and those undergoing chronic hemodialysis (CHD) treatment are at high risk of infection with hepatitis $\mathrm{C}$ virus (HCV). The incidence of occult $\mathrm{HCV}$ infection $(\mathrm{OCl})$ in $\mathrm{CHD}$ remains controversial and the real burden of HCV in this population may be affected by the rate of $\mathrm{OCl}$. This study evaluates the molecular assessment of $\mathrm{OCl}$ in CHD in an Iranian population.

Methods: All subjects on CHD in the South Khorasan province of Iran were invited for participation in the study. Whole blood samples were taken and serological, clinical, and demographic information was recorded. HCV-RNAs were checked in serum and peripheral blood mononuclear cells (PBMCs) using an in-house semi-nested PCR assay. Viral load was determined using a real-time PCR-based quantification kit. Sequencing was performed to determine genotypes.

Results: Overall, 120 cases participated in the study; $57.5 \%$ were male and the rest were female. In serum samples, no positive case was found for HCV-RNA. In PBMC samples, 2/120 (1.6\%) were positive for HCV-RNA (95\% Cl, 0.002 to 0.059 ); the mean age of $\mathrm{OCl}$ positive cases was $37.5 \pm 19.2$ years which was significantly lower than $\mathrm{OCI}$ negative cases $(P=0.026)$. Only one case had detectable viral load which was $49 \mathrm{IU} / \mathrm{mL}$. The only HCV genotype identified was $1 \mathrm{a}$.

Conclusion: This study showed that there is a risk of OCl among CHD patients; the very low and undetectable viral loads of OCI warrant further follow-up molecular testing for earlier diagnosis and treatment in the era of DAA.

Keywords: Dialysis, Genotype, Hemodialysis, Hepatitis C virus, Occult HCV

Cite this article as: Taherpour S, Javanmard D, Ziaee M. Occult hepatitis C virus infection among hemodialysis patients: an Iranian experience. Arch Iran Med. 2020;23(9):586-592. doi: 10.34172/aim.2020.68.
\end{abstract}

Received: December 14, 2019, Accepted: March 9, 2020, ePublished: September 1, 2020

\section{Introduction}

Hepatitis $\mathrm{C}$ virus (HCV) infection is still a major health concern around the world. Globally, 71 million people are estimated to have chronic HCV infection with 399000 HCV-related deaths occurring in 2016, mostly from cirrhosis and hepatocellular carcinoma. ${ }^{1}$ The rate of $\mathrm{HCV}$ infection is in close association with intravenous drug use, sharing needles or syringes, tattooing, multiple sexual partners, blood transfusion, hemodialysis, and etc. ${ }^{2-5}$

However, with the advent of direct acting antivirals (DAA), there are promising prospects in reduction of $\mathrm{HCV}$ burden. In Iran, the prevalence of $\mathrm{HCV}$ is estimated at $0.3 \%$ among the general population, $6.2 \%$ among intermediate risk populations, and $32.1 \%$ among highrisk populations, which is lower than other countries. ${ }^{6}$

The newly identified type of $\mathrm{HCV}$ infection, the occult HCV infection (OCI), is defined as the presence and detection of HCV-RNA in hepatocytes and/or in peripheral blood mononuclear cells (PBMCs) in the absence of, or undetectable HCV-RNA in serum. ${ }^{7}$ OCI can be observed in two types: seropositive (positive for anti-HCV but negative for HCV-RNA), and cryptogenic $\mathrm{HCV}$ infection (negative for the both markers). ${ }^{8} \mathrm{OCI}$ is important in terms of transmission, hepatic diseases, and even extrahepatic tissue damage (lymphoproliferative disorders, glomerulopathies and end-stage renal disease [ESRD]).

Chronic kidney disease (CKD) and ESRD are global major health conditions which are mostly progressive, irreversible conditions. ${ }^{10}$ Globally, the incidence of ESRD has been increasing in both developing and developed countries over the last decades. ${ }^{11}$ Similarly in Iran, it increased from 467 in 2006 to 507 per one million in $2010 .^{12}$

Dialysis is the most common reliable and accessible therapeutic approach in ESRD which increases survival and life expectancy in patients. ${ }^{10}$ Despite the screening tests on blood products and devices, nosocomial infections are one of leading causes of morbidity and mortality in ESRD. ${ }^{13} \mathrm{HCV}$ is more prevalent in ESRD compared to the general population, ${ }^{14}$ with an overall prevalence of $9.9 \%$ among chronic hemodialysis (CHD) patients in high- and middle-income countries. ${ }^{15}$ According to a recent metaanalysis, the overall prevalence of anti-HCV among CHD patients in Iran was estimated at 8.3\% ranging from $0.0 \%$ to $31.4 \%{ }^{6}$. This is far higher than the $0.3 \%$ rate in the 
general population of Iran.

The mortality and morbidity of kidney transplant patients positive for HCV are higher than those of nonHCV infected individuals. ${ }^{16}$ Although use of DAAs as a new therapeutic regimen has resulted in considerable improvement in management of CHD patients, ${ }^{17}$ there are some recent findings on the observation of OCI in those who have developed sustained virologic response after DAA treatment. ${ }^{18,19}$ The global reported prevalence of OCI in CHD patients is extremely variable with a range between zero and $45 \%,{ }^{20}$ which seems to have been affected by the regional epidemiology of $\mathrm{HCV}$ as well as access to new treatments. Note that there is significant controversy on this topic, and information is still limited on OCI in CHD populations.

In the clinical setting, although an OCI infection may lead to milder consequences compared to overt infection, ${ }^{21}$ there is the possibility of transmission of OCI to others in dialysis units. ${ }^{22}$ Thus, diagnosis, follow-up, and treatment of OCI cases are recommended. Considering the variable global data on OCI and the limited information from Iran, especially eastern Iran, we aimed to evaluate the prevalence of OCI among patients undergoing maintenance dialysis in South Khorasan, eastern Iran.

\section{Material and Methods}

Study Settings and Patients

This was a cross-sectional study conducted between July 2018 and May 2019 in the hemodialysis units in the South Khorasan province of Iran. An informed consent was signed by the patients, and all of them completed a questionnaire including all related risk factors and demographic information. All the patients had been previously checked for anti-HCV (anti-HCV; Hepanostika HCV ultra, Beijing United Biomedical Co. LTD. Beijing, China) and the corresponding data were collected.

\section{Sampling}

A general call was sent out to all dialysis centers of the region, explaining the goals and details of the plan. According to the health statistics of the province, there were totally 150 patients undergoing maintenance dialysis in the province. Whole blood samples were taken from the participants, and a questionnaire was completed. PBMCs were isolated using a Ficoll-Histopaque density gradient. Isolated PBMC and plasma contents were aliquoted into two tubes; one was used fresh for RNA isolation and the other was persevered at $-70^{\circ} \mathrm{C}$ until further experiments.

\section{RNA Extraction and cDNA Synthesis}

The tubes containing the PBMC were centrifuged and the cell pellets underwent RNA isolation using a Triazole approach. The RNA from serum samples was isolated using viral RNA extraction kit, according to the manufacturer's instructions (Viral DNA/RNA extraction kit, FAVORGEN Biotech Corp, Ping-Tung, Taiwan). The purity of obtained RNAs was checked by a BioPhotometer (Nanodrop 1000), and the integrity was assessed by resolving the RNA on agarose gel (Figure 1); the ratio of 260/280 was $\geq 1.6$. The RNA products (About $4 \mu \mathrm{g}$ total RNA) were prepared for synthesis of cDNA using a random hexamer primer and applying the First Strand cDNA Synthesis Kit according to the kit's instructions (Thermo Fisher Scientific, Massachusetts, USA).

\section{Detection of HCV-RNA}

Utilizing an alignment of 5'-UTR region of all known HCV genotypes, a semi-nested primer set was designed which allowed for detecting all HCV genotypes. The primers were as follows: HCF1: 5'-CGGTGAGTACACCGGAAT-3', HCF2: 5'-GCCTTGTGGTACTGCCTGAT-3', HCR: 5'-ATGTACCCCATGAGRTCGG-3'. The first PCR reaction was performed in a final volume of $40 \mu \mathrm{L}$ containing $4 \mu \mathrm{L}$ of reverse transcription solution, $2 \mathrm{X}$ PCR master mix (Red, Amplicon), and 20 pmole of outer primers (HCF1 and HCR). The PCR program began at $95^{\circ} \mathrm{C}$ for 5 minutes, followed by 45 cycles including $94^{\circ} \mathrm{C}$ for 20 seconds, $54^{\circ} \mathrm{C}$ for 20 seconds and $72^{\circ} \mathrm{C}$ for 50 seconds. Then, an extra extension step was applied for 5 minutes in order to produce full-length 595 base-pair strands. For the nested run, $2 \mu \mathrm{L}$ of the first PCR product was applied in a reaction with $25 \mu \mathrm{L}$ final volume using inner primes (HCF2 and HCR) under conditions similar to the first one (The annealing temperature was $56^{\circ} \mathrm{C}$, and extension was performed for 30 seconds) for amplification of $474 \mathrm{bp}$ segments of $5^{\prime}$-UTR region of HCV-RNA. The sensitivity of designed primers was checked on approved HCV genotypes $1 \mathrm{a}, 1 \mathrm{~b}, 2 \mathrm{a}, 2 \mathrm{~b}, 3 \mathrm{a}, 4 \mathrm{a}$, and $5 \mathrm{a}$ that were kindly donated by Dr. M.H Karbalaie Niya, Firouzgar hospital.

The designed primers were checked to detect HCV genotypes including 1a, 1b, 2a, 2b, 3a, 4a, and 5a. One positive sample with a known concentration was serially diluted and then forwarded for determining the lower limit of detection (LLOD) for the designed primers. The result showed that this semi-nested PCR had an LLOD of $14 \mathrm{IU} / \mathrm{mL}$ (Figure 1).

\section{Determination of HCV Viral Load}

Viral load was determined using RoboGeneR HCV RNA Quantification kit (AJ Roboscreen GmbH, Germany), as described by the instructions of the kit (The lower limit of detection for the kit was $16.6 \mathrm{IU} / \mathrm{mL}$ ).

\section{HCV Genotyping}

Sequencing of 5'-UTR region was performed to determine the genotypes. For this purpose, the semi-nested PCR products were subjected to a Gel/PCR purification kit according to the manufacturer's instructions (Favorgen Biotech). The sequence of purified PCR products was 

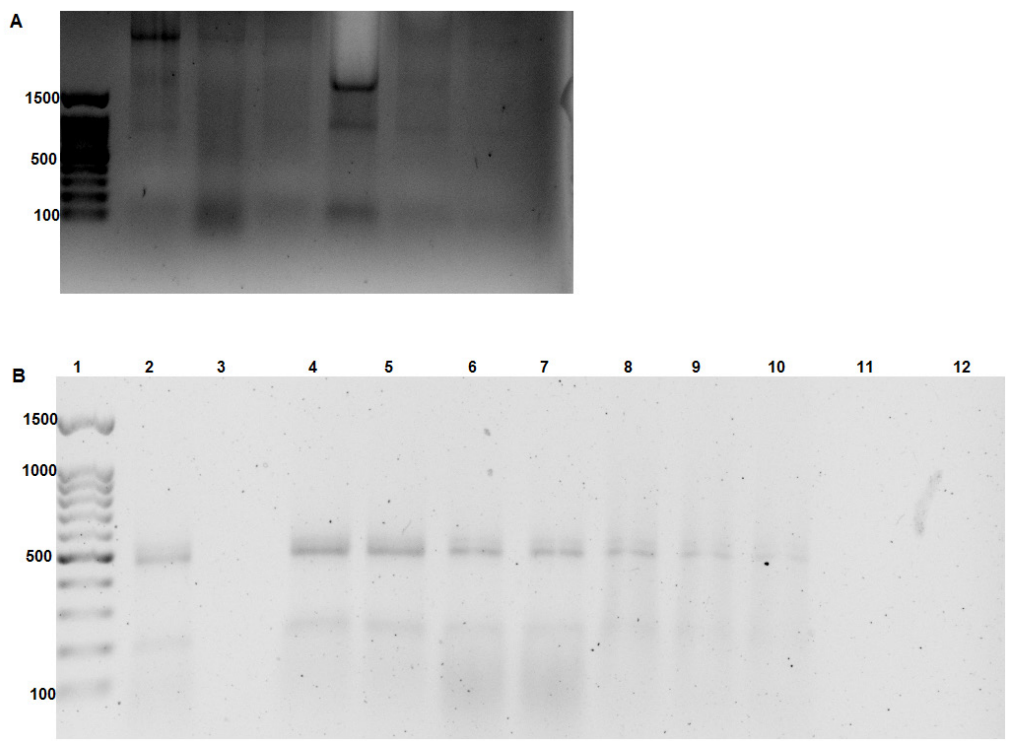

Figure 1. A) The product of RNA extraction was resolved on 1\% agarose gel determining the integrity of RNA obtained. B) The result of LLOD determination was revealed after serial dilution of a sample with known concentration and implementation of PCR with the semi-nested PCR. Lane 1 is a 100 bp DNA size marker, lane 2: Positive control, lane 3: Negative control, lane 4: A known sample with $1.4 \times 10^{7} \mathrm{IU} / \mathrm{mL}$, lane 5: $1.4 \times 10^{6}$, lane $6: 1.4 \times 10^{5}$, lane $7: 1.4 \times 10^{4}$, lane 8: $1.4 \times 10^{3}$, lane 9: $1.4 \times 10^{2}$, lane 10: 14, lane 11: 1.4, and lane 12: $0.14 \mathrm{IU} / \mathrm{mL}$

determined using BigDye terminator assay (Metabion international AG, Planegg/Steinkirchen, Germany). The raw sequence data were analyzed in BioEdit software, after which Mega 7 software was employed for construction of the phylogenetic tree using the attribute sequence of all HCV genotypes.

\section{Statistical Analysis}

All the information was recorded and analyzed using IBM SPSS version 25 (IBM Corp., Armonk, NY, USA). Descriptive statistics and mean values were obtained. Estimation of continuous and quantitative variables was performed using chi-square and Mann-Whitney $U$ tests. Also, the risk factors were analyzed using chi-square tests.

\section{Results}

Baseline Information and Risk Factors

Overall, there were 150 patients with CHD maintenance in the South Khorasan province. Among them, 30 cases did not participate in the study; the reasons were long distance to the sampling centers, having a respiratory illness, being away on a trip, unwillingness to participate, and old age, fatigue, weakness and lethargy. Totally, 120 cases were willing and available to participate in the study; $57.5 \%$ were male and the rest were female. The mean age of the patients was $59.5 \pm 14.1$ years which varied from 21 to 88 years; the range and median were 67 and 61 years, respectively.

According to the information obtained from the questionnaires, hypertension was the most prominent risk factor observed among the HD patients $(67.5 \%)$. Other conditions were as follows: diabetes $(50.8 \%)$, history of blood transfusion $(47.5 \%)$, and history of endoscopy
(45\%), history of seizures (7.5\%), smoking (5\%), acupuncture (4.2\%), non-injecting addiction (5.8\%), and imprisonment $(1.7 \%)$. The mean length of dialysis during the lifetime of patients was $3.1 \pm 3.1$ years which varied from 1 month to 17 years; the range and median were 16.1 and 3.1 years, respectively.

\section{Detection of OCI}

Among the cDNA templates of serum samples, no positive case for HCV-RNA was found (95\% CI, 0.00 to 0.031 , Clopper-Pearson method). In the PBMC samples, two were found positive for HCV-RNA, one of whom was antiHCV positive. Overall, 2/120 (1.6\%) were found positive for OCI $(95 \% \mathrm{CI}, 0.002$ to 0.059 , Clopper-Pearson method); their mean age was $37.5 \pm 19.2$ years. Regarding gender, one was male and the other OCI-positive case was female $(1.4 \%$ vs $2 \%)$, and both were married and had academic education level. Both OCI-positive cases had been undergoing HD three times per week for 2 years and 6 years, respectively. Totally, four patients had a history of kidney transplantation, one of whom (25\%) was OCIpositive $(P=0.066)$. Regarding the low prevalence of OCI detected, there was no significant association with the risk factors. In terms of dialysis duration, the rate of OCI was $0.00,1.5 \%$ and $2.5 \%$ among those with less than one year, $1-5$ years and more than 5 years of dialysis, respectively. This result showed an increased pattern of OCI proportional to the duration of dialysis; however, due to the small number of cases positive for OCI, this correlation was not statistically significant $(P=0.806)$.

Viral Load of OCI and Genotypes

The viral load was determined through RoboGeneR HCV 
RNA Quantification, as described by the kit's instructions (The lower limit of detection for the kit was $16.6 \mathrm{IU} / \mathrm{mL}$ ). Of the two samples, only one had a detectable viral load which was $49 \mathrm{IU} / \mathrm{mL}$. Sequencing of $5^{\prime}$-UTR region of $\mathrm{HCV}$ revealed that isolates of the current study belonged to the genotype 1a (Figure 2). The evolutionary history was inferred using the Maximum Likelihood method based on the Kimura 2-parameter model applied using the MEGA7 software.

\section{Discussion}

Kidney transplant patients and those on CHD are amongst the most significant groups in terms of $\mathrm{HCV}$-associated clinical consequences. Nevertheless, there is still not enough clinical and epidemiological data on OCI among CHD groups. Furthermore, the global prevalence of HCV infection is extremely variable according to varied rates of reported OCI. Thus, lack of evidence on OCI in CHD groups leads to an underestimation in the real burden of $\mathrm{HCV}$ in these populations.

This study showed $1.6 \%$ prevalence of OCI in subjects with CHD in the South Khorasan province, eastern Iran. There has been no report from eastern Iran, and this is the first assessment of OCI in the region. Meanwhile,

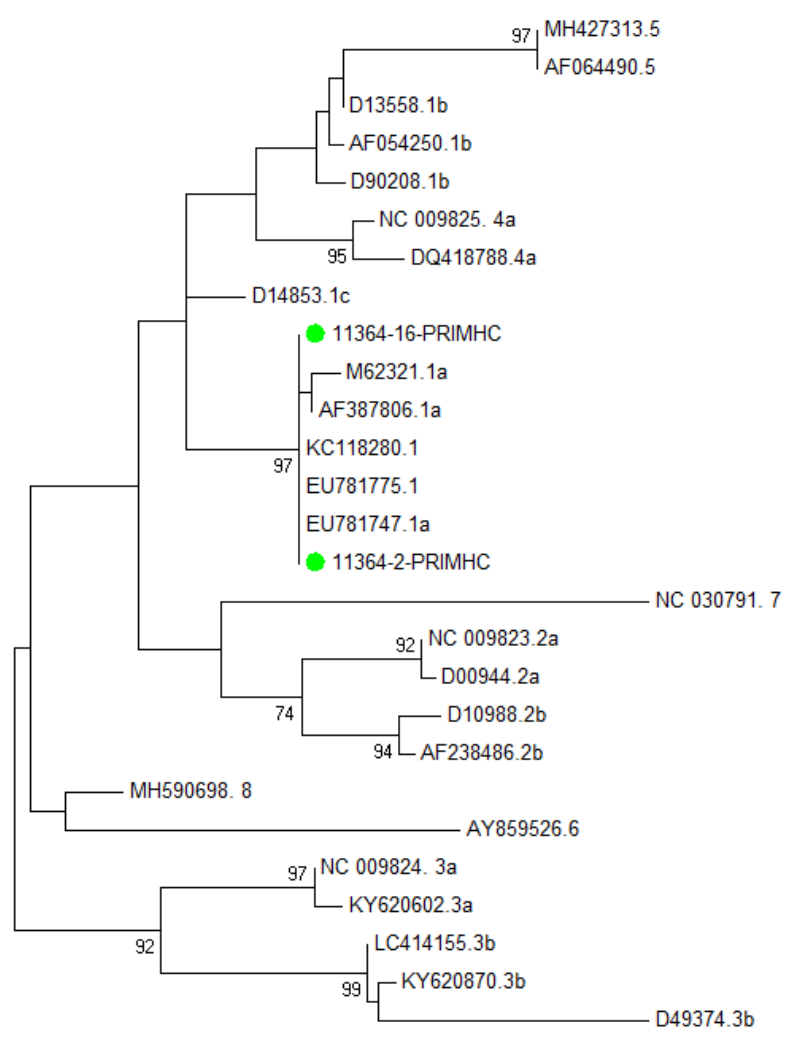

$\longmapsto .02$

Figure 2. Illustration of the Phylogenetic Analysis of HCV Isolates of the Current Study Along with All Known Genotypes; the accession number and genotypes are given in front of the branches. Items labeled with green circle are reported from the current study. there have been limited studies from other regions of Iran: $0 \%$ in a report by Eslamifar et al on $70 \mathrm{HD}$ patients in Tehran, ${ }^{14}$ and $3.03 \%$ among $200 \mathrm{HD}$ patients in an earlier study in Tehran. ${ }^{23}$ These two reports are in line with the present study and support the fact that Iran has a very low prevalence of HCV. Nevertheless, most recently, an Iranian assessment reported $11.3 \%$ OCI among 515 cases on CHD. ${ }^{24}$ This study is in apparent contradiction with previous Iranian studies as well as ours, which can be explained based on the large sample size, inclusion criteria, and probably regional diversity of the samples.

The prevalence reported in the present work has strong consistency with the rate of HCV in Iran, as well as the study region. The prevalence of $\mathrm{HCV}$ is estimated at $0.3 \%$ among the general population, ${ }^{6}$ while in the general population of the study region, the prevalence of anti-HCV has been reported at $0.2 \% .{ }^{25}$ On the other hand, among the $41 \mathrm{CHD}$ cases of this province, the rate of $\mathrm{HCV}$ viremia was $2.4 \%$ at $2014 .^{26}$ These findings support the low prevalence of OCI observed in this study. In other countries, higher prevalence rates of OCI have been reported compared to Iranian studies which seems to be highly associated with the higher prevalence of overt HCV infection and the rate of anti-HCV in those regions. In Spain, the rate of OCI across CHD groups was reported from $15 \%$ to $45 \%{ }^{27-29}$ Spain is one of most HCV-prevalent regions in the European Union, with the prevalence rate in the adult population estimated at $2.64 \%$ in $2011 .^{30}$ In Egypt, which is the most prevalent $\mathrm{HCV}$ region in the world with a national estimation of $14.7 \%,{ }^{31}$ the rate of OCI among CHD in different centers was reported at $3.7 \%$ out of $81,{ }^{32} 4.8 \%$ out of $62,{ }^{21}$ and $23 \%$ out of $40,{ }^{33}$ though further large sample studies are still warranted in terms of OCI. These high rates of OCI suggest the need for strict following and preventive control programs among the CHD units. Furthermore, these findings represent an implicit association between the rates of $\mathrm{HCV}$ in each region with the rates of OCI observed among high risk groups.

Among the two OCIs identified, one had $49 \mathrm{IU} / \mathrm{mL}$ viral load while the other had no detectable viral load, which is in accordance with most previous studies, ${ }^{21,32,34-36}$ although some studies have found higher titers. ${ }^{33}$ This observation can be explained by the probable underlying mechanisms of OCI: low levels of infected hepatocytes, specific CD markers in immune responses, and memory $\mathrm{T}$ cell activation, which all can be involved in the suppressed status of HCV replication to a very low or undetectable levels. ${ }^{37}$ It has been determined that low copies of HCV as few as 20 copies can be transmitted and be infectious, ${ }^{38}$ where HCV can be potentially infectious in surfaces for at least 16 hours. ${ }^{39}$ On the other hand, a few studies determined OCI as a replicating form of $\mathrm{HCV}$ with the capability of transmission and infection. Previous molecular epidemiological studies have shown nosocomial 
transmission of $\mathrm{HCV}$ in dialysis units. ${ }^{4}$ Primarily, this can be due to underlying diseases including diabetes and CKDs resulting in weakened cellular immunity. ${ }^{40}$ Furthermore, the operation of hemodialysis includes events that increase the risk of exposure to bloodborne pathogens which constantly occur during the patient's lifetime: blood transfusion, equipment, medication re-use, surgical operations, contaminated surfaces, gloves, patient trays, fistula lavage sinks, etc. ${ }^{39,41}$

Although blood transfusion was recorded among $47.5 \%$ of the studied participants, it was not associated with the incidence of OCI; this can be due to the small number of OCI observed in the current study. However, blood transfusion has been previously associated with higher prevalence of OCI. ${ }^{33,42,43}$ Among the risk factors, hypertension was the most prominent risk factor observed among the studied CHD patients (67.5\%), followed by diabetes $(50.8 \%)$, blood transfusion $(47.5 \%)$, and history of endoscopy (45\%). Furthermore, some of these conditions have been previously described to be in association with other bloodborne pathogens in the region of study. ${ }^{44}$

The isolates identified in the study belonged to the genotype 1a. The HCV genotype 1a has been determined as the most prevalent HCV genotype in Iran followed by genotype $3,{ }^{6}$ as with most parts of the world ${ }^{45}$. Thus, our result is consistent with previous regional and global studies. In the region of the study, namely the South Khorasan province, previous studies have determined the HCV genotype $3 \mathrm{a}$ followed by $1 \mathrm{a}$ as the most prevalent. ${ }^{46-48}$ The discrepancy with the results of those studies can be due to the population type and the time of studies; all those studies were among prisoners and hemophiliacs implemented before the advent of DAAs treatment. Nevertheless, one study conducted in Iran revealed the very low dominance of the $1 \mathrm{a}$, while instead $1 \mathrm{~b}$ was most prevalent among Azerbaijani patients ${ }^{49}$ which is highly in line with former Soviet Union regions. ${ }^{50}$

In conclusion, this study showed that there is a risk of OCI among CHD patients, and the very low and undetectable viral loads of OCI suggest that more follow-up molecular actions are required for monitoring, diagnosis, and treatment of $\mathrm{HCV}$-infected patients.

\section{Authors' Contribution}

MZ: get the idea, designed, supervised the study and critical reviewing of manuscript. ST: performed sampling, collection of data, experiments and data analysis. DJ: designed and performed experimental procedures and drafting manuscript.

\section{Conflict of Interest Disclosures}

All the authors have stated there is no conflict to declare.

\section{Ethical Statement}

This project was approved by the research ethics committee of Birjand University of Medical Sciences (BUMS), with the ethical code number IR.BUMS.REC.1397.85.

\section{Acknowledgements}

This work was fully supported and funded by Birjand University of Medical Sciences (BUMS). Sincere efforts by the staff of Imam Reza and Razi hospitals and other dialysis units as well as the cooperation of all patients are much appreciated. This work was fully supported and funded by Birjand University of Medical Sciences (BUMS). Sincere efforts by the staff of Imam Reza and Razi hospitals and other dialysis units as well as the cooperation of all patients are much appreciated.

\section{References}

1. World Health Organization. Hepatitis C. Available from: https://www.who.int/news-room/fact-sheets/detail/hepatitis-c. Accesed 27 July 2020.

2. Pradat $P$, Virlogeux $V$, Trépo E. Epidemiology and elimination of HCV-related liver disease. Viruses. 2018;10(10):545. doi: 10.3390/v10100545.

3. Fabrizi F, Messa P. The epidemiology of HCV infection in patients with advanced CKD/ESRD: A global perspective. Semin Dial. 2019;32(2):93-8. doi: 10.1111/sdi.12757.

4. Nguyen DB, Bixler D, Patel PR. Transmission of hepatitis C virus in the dialysis setting and strategies for its prevention. Semin Dial. 2019;32(2):127-34. doi: 10.1111/sdi.12761.

5. Ghafari S, Sharifzadeh G, Jamali S, Taji B, Javadmoosavi SY, Ziaee M. Prevalence of Hepatitis B and C among DrugAbusing Male Prisoners in Birjand, South Khorasan, Iran. Arch Iran Med. 2019;22(9):501-4.

6. Mahmud S, Akbarzadeh V, Abu-Raddad LJ. The epidemiology of hepatitis C virus in Iran: Systematic review and metaanalyses. Sci Rep. 2018;8(1):150. doi: 10.1038/s41598-01718296-9.

7. Bartolome J, Lopez-Alcorocho JM, Castillo I, Rodriguez-Inigo E, Quiroga JA, Palacios R, et al. Ultracentrifugation of serum samples allows detection of hepatitis $C$ virus RNA in patients with occult hepatitis C. J Virol. 2007;81(14):7710-5. doi: 10.1128/JVI.02750-06.

8. Welker MW, Zeuzem S. Occult hepatitis C: How convincing are the current data? Hepatology. 2009;49(2):665-75. doi:10.1002/hep.22706.

9. Sette LH, de Almeida Lopes EP, dos Anjos NC, Valente LM, de Oliveira SA, Lucena-Silva N. High prevalence of occult hepatitis $\mathrm{C}$ infection in predialysis patients. World J Hepatol. 2019;11(1):109-18. doi: 10.4254/wjh.v11.i1.109.

10. Barzegar H, Jafari H, Charati JY, Esmaeili R. Relationship Between Duration of Dialysis and Quality of Life in Hemodialysis Patients. Iran J Psychiatry Behav Sci. 2017; 11(4):e6409. doi: 10.5812/ijpbs.6409.

11. Mousavi S, Soleimani A, Mousavi M. Epidemiology of endstage renal disease in Iran: A review article. Saudi J Kidney Dis Transpl. 2014;25(3):697-702.

12. Najafi I, Alatab S, Atabak S, Majelan NN, Sanadgol H, Makhdoomi K, et al. Seventeen years' experience of peritoneal dialysis in Iran: first official report of the Iranian peritoneal dialysis registry. Perit Dial Int. 2014;34(6):636-42. doi: $\quad$ 10.3747/pdi.2012.00054.

13. Lamarche $\mathrm{C}$, Iliuta IA, Kitzler T. Infectious disease risk in dialysis patients: a transdisciplinary approach. Can j kidney health dis. 2019;6:2054358119839080. doi: $10.1177 / 2054358119839080$.

14. Eslamifar A, Ramezani A, Ehteram H, Razeghi E, Ahmadi F, Amini $M$, et al. Occult hepatitis $C$ virus infection in Iranian hemodialysis patients. J Nephropathol. 2015;4(4):116-20. doi: 10.12860/jnp.2015.22.

15. Natov $S$, Pereira BJ. Hepatitis C virus infection in patients on maintenance dialysis. UpToDate (since Oct 2005), edited by 
Rose B, Wellesley, MA, UpToDate, Inc. 2005.

16. Scott DR, Wong JK, Spicer TS, Dent H, Mensah FK, McDonald $S$, et al. Adverse impact of hepatitis $C$ virus infection on renal replacement therapy and renal transplant patients in Australia and New Zealand. Transplantation. 2010;90(11):1165-71. doi: 10.1097/TP.0b013e3181f92548.

17. Del Bello A, Abravanel F, Alric L, Lavayssiere L, Lhomme S, Bellière J, et al. No evidence of occult hepatitis $C$ or $E$ virus infections in liver-transplant patients with sustained virological response after therapy with direct acting agents. Transplant Infect Dis. 2019:e13093. doi:10.1111/tid.13093.

18. Wang Y, Rao H, Chi X, Li B, Liu H, Wu L, et al. Detection of residual HCV-RNA in patients who have achieved sustained virological response is associated with persistent histological abnormality. EBioMedicine. 2019;46:227-35. doi: 10.1016/j. ebiom.2019.07.043

19. Elmasry S, Wadhwa S, Bang BR, Cook L, Chopra S, Kanel $\mathrm{G}$, et al. Detection of Occult Hepatitis C Virus Infection in Patients Who Achieved a Sustained Virologic Response to Direct-Acting Antiviral Agents for Recurrent Infection After Liver Transplantation. Gastroenterology. 2017;152(3):550-3. e8. doi: 10.1053/j.gastro.2016.11.002.

20. Dolatimehr F, Khosravi MH, Rezaee-Zavareh MS, Alavian SM. Prevalence of occult HCV infection in hemodialysis and kidney-transplanted patients: a systematic review. Future Virol. 2017;12(5):315-22. doi: 10.2217/fvl-2016-0138.

21. Abdelmoemen G, Khodeir SA, Abou-Saif S, Kobtan A, AbdElsalam S. Prevalence of occult hepatitis $C$ virus among hemodialysis patients in Tanta university hospitals: a singlecenter study. Environ Sci Pollut Res. 2018;25(6):5459-64. doi: 10.1007/s11356-017-0897-y.

22. Barril G, Castillo I, Arenas MD, Espinosa M, Garcia-Valdecasas J, Garcia-Fernandez N, et al. Occult hepatitis C virus infection among hemodialysis patients. J Am Soc. Nephrol. 2008;19(12):2288-92. doi: 10.1681/ASN.2008030293.

23. Naghdi R, Ranjbar M, Bokharaei-Salim F, Keyvani H, Savaj $\mathrm{S}$, Ossareh $\mathrm{S}$, et al. Occult hepatitis $\mathrm{C}$ infection among hemodialysis patients: a prevalence study. Ann Hepatol. 2017;16(4):510-3. doi: 10.5604/01.3001.0010.0277.

24. Ayadi A, Nafari AH, Sakhaee F, Rajabi K, Ghaderi Y, Rahimi Jamnani $\mathrm{F}$, et al. Host genetic factors and clinical parameters influencing the occult hepatitis $\mathrm{C}$ virus infection in patients on chronic hemodialysis: Is it still a controversial infection? Hepatol Res. 2019;49(6):605-16. doi: 10.1111/hepr.13325.

25. Ebrahimzadeh A, Azarkar Z, Ziaee M, Sharifzadeh G, Bijari B. Prevalence and risk factors of hepatitis $\mathrm{c}$ infection (HCV) in Birjand, Iran, 2014. Int J Infect Dis. 2016; 3(1):34102. doi: 10.17795/iji-34102.

26. Ziaee M, Azizee R, Namaei MH. Prevalence of HCV infection in hemodialysis patients of South Khorasan in comparison With HBV, HDV, HTLV I/II, And HIV infection. Bangladesh j med sci. 2014;13(1):36-9. doi: 10.3329/bjms.v13i1.13903.

27. Jiménez C, Olea T, Santana M, Lopez M, Castillo I, Bartolomé J, et al. Occult hepatitis $C$ virus in recipients of kidney transplantation: prevalence and clinical implications. Transplantation. 2018;102:S658. doi: 10.1097/01. tp.0000543589.88342.67.

28. Barril G, Castillo I, Arenas MD, Espinosa M, Garcia-Valdecasas J, Garcia-Fernández N, et al. Occult hepatitis C virus infection among hemodialysis patients. J Am Soc Nephrol. 2008;19(12):2288-92. doi: 10.1681/ASN.2008030293.

29. Castillo I, Martinez-Ara J, Olea T, Bartolomé J, Madero R, Hernández $\mathrm{E}$, et al. High prevalence of occult hepatitis $\mathrm{C}$ virus infection in patients with primary and secondary glomerular nephropathies. Kidney Int. 2014;86(3):619-24. doi: 10.1038/ ki.2014.68.

30. Cornberg M, Razavi HA, Alberti A, Bernasconi E, Buti M, Cooper C, et al. A systematic review of hepatitis C virus epidemiology in Europe, Canada and Israel. Liver Int. 2011;31(s2):30-60. doi:10.1111/j.1478-3231.2011.02539.x.

31. Gomaa A, Allam N, Elsharkawy A, El Kassas M, Waked I. Hepatitis C infection in Egypt: prevalence, impact and management strategies. Hepat Med. 2017;9:17-25. doi: 10.2147/HMER.S113681.

32. Abdelrahim SS, Khairy R, Esmail MA-M, Ragab M, AbdelHamid M, Abdelwahab SF. Occult hepatitis C virus infection among Egyptian hemodialysis patients. J Med Virol. 2016;88(8):1388-93. doi:10.1002/jmv.24467.

33. Ali NK, Mohamed RR, Saleh BE, Alkady MM, Farag ES. Occult hepatitis C virus infection among haemodialysis patients. Arab J Gastroenterol. 2018;19(3):101-5. doi:10.1016/j. ajg.2018.09.001.

34. Aboalam H, Rashed H-A, Mekky M, Nafeh H, Osman O. Prevalence of occult hepatitis $\mathrm{C}$ virus in patients with HCVantibody positivity and serum HCV RNA negativity. J Curr Med Res Pract. 2016;1(2):12-6. doi: 10.4103/2357-0121.192539.

35. Gatserelia L, Sharvadze L, Karchava M, Dolmazashvili E, Tsertsvadze T. Occurrence of occult HCV infection among Hiv infected patients in Georgia. Georgian med news. 2014(226):37-41.

36. De Marco L, Manzini P, Trevisan M, Gillio-Tos A, Danielle $\mathrm{F}$, Balloco $\mathrm{C}$, et al. Prevalence and follow-up of occult HCV infection in an Italian population free of clinically detectable infectious liver disease. PLoS One. 2012;7(8):e43541-e. doi:10.1371/journal.pone.0043541.

37. Kaźmierczak J, Pawełczyk A, Cortes KC, Radkowski M. Seronegative Hepatitis C Virus Infection. Arch Immunol Ther Exp. 2014;62(2):145-51. doi:10.1007/s00005-013-0257-7.

38. Martínez-Rodríguez MD, Uribe-Noguez LA, Arroyo-Anduiza $\mathrm{Cl}$, Mata-Marin JA, Benitez-Arvizu G, Portillo-López ML, et al. Prevalence and risk factors of Occult Hepatitis C infections in blood donors from Mexico City. PLoS One. 2018;13(10):e0205659. doi:10.1371/journal.pone.0205659.

39. Constancio NS, Ferraz MLG, Martins CTB, Kraychete AC, Bitencourt PL, Nascimento MMd. Hepatitis C in Hemodialysis Units: diagnosis and therapeutic approach. J Bras Nefrol. 2019;41(4):539-49. doi:10.1590/2175-8239-jbn-2018-0177.

40. KARKAR A. Hepatitis $C$ in dialysis units: The Saudi experience. Hemodial Int. 2007;11(3):354-67. doi:10.1111/j.15424758.2007.00192.x.

41. Sauné K, Kamar N, Miédougé M, Weclawiak H, Dubois M, Izopet J, et al. Decreased prevalence and incidence of HCV markers in haemodialysis units: a multicentric French survey. Nephrol Dial Transplant. 2010;26(7):2309-16. doi:10.1093/ ndt/gfq696.

42. Han LI, Wang SX. Hepatitis C viral infection in a Chinese hemodialysis unit. Chin Med J. 2010;123(24):3574-7. doi: 10.3760/cma.j.issn.0366-6999.2010.24.013.

43. Youssef SS, Nasr AS, El Zanaty T, Rawi E, Sayed R, Mattar MM. Prevalence of occult hepatitis $C$ virus in egyptian patients with chronic lymphoproliferative disorders. Hepat Res Treat. 2012;2012:429784. doi:10.1155/2012/429784.

44. Javanmard D, Alavian SM, Abedi F, Namaei MH, Asghari A, Ziaee M. High Prevalence of Hepatitis B Virus Infection in the Village of Esfandiar in South Khorasan Province, Iran. Hepat Mon. 2018;18(8):e65473. doi:10.5812/hepatmon.65473.

45. Messina JP, Humphreys I, Flaxman A, Brown A, Cooke GS, Pybus OG, et al. Global distribution and prevalence of hepatitis C virus genotypes. J Hepatol. 2015;61(1):77-87. doi:10.1002/hep.27259. 
46. Azarkar Z, Sharifzadeh G, Fereidouni M. Assessing the Hepatitis C Genotype in Prisoners Infected with HCV in South Khorasan-2014. Modern Care J. 2018;15(2).

47. Ziaee M, Zarban A, Malekinejad P, Akhbary H. Evaluation of HGV viremia prevalence and its co-infection with HBV, HCV, HIV and HTLV-1 in hemophilic patients of Southern Khorassan, Iran. Hepat Mon. 2007;7(1):11-4.

48. Ziaee M, Namaei MH, Azarkar G. The prevalence of HTLV-1 and its Co-Infection with HCV, HBV and HIV in Hemophilic patients. Pak J Med Sci. 2015;31(5):1246-9. doi: 10.12669/ pjms.315.7888

49. Bokharaei-Salim F, Keyvani H, Monavari SH, Alavian SM, Fakhim S, Nasseri S. Distribution of hepatitis C virus genotypes among azerbaijani patients in capital city of iran-tehran. Hepat Mon. 2013;13(9):e13699-e. doi: 10.5812/hepatmon.13699.

50. Viazov S, Kuzin S, Paladi N, Tchernovetsky M, Isaeva E, Mazhul L, et al. Hepatitis C virus genotypes in different regions of the former Soviet Union (Russia, Belarus, Moldova, and Uzbekistan). J Med Virol. 1997;53(1):36-40. doi:10.1002/ (SICI)1096-9071(199709)53:1<36::AID-JMV7>3.0.CO;2-R. 